\title{
Article \\ Evaluation of Antibody Titre of Dogs Vaccinated against Canine Distemper in Jos, Plateau State
}

\section{Kenneth Ikejiofor Ogbu}

Federal College of Animal Health and Production Technology, Vom, Plateau State, Nigeria; kenike_mary@yahoo.com; +2348030852357

\begin{abstract}
Determination of antibody titre of dogs vaccinated against canine distemper in Jos North and South local Government Areas of Plateau State was carried out by collection of sera of vaccinated dogs and administration of well-structured questionnaires to dog owners. The samples collected were analyzed using the immune-blot ELISA Kit to determining the antibody titre (immunoglobulin G). It indicated that dogs vaccinated against the disease mounted adequate protective immunity. The result revealed that 54 $(90.0 \%)$ of the sampled dogs have protective immunity, with those given more than one dose having higher level of protective antibody. Statistically, the result showed that the antibody titre did not differ significantly in relation to immunity and sex, breed, age and location but significant difference was seen in relation to number of primary vaccination. The result also revealed that those dogs that received booster doses (secondary vaccination) had more protective antibody. The study was aimed at evaluating the antibody titre of dogs vaccinated against canine distemper in Jos, Plateau State.
\end{abstract}

Keywords: antibody titre; vaccination; dog; canine distemper virus; Jos

\section{INTRODUCTION}

Canine distemper (CD) in dogs is caused by the canine distemper virus (CDV) a member of the genus Morbilivirus in the Paramyxoviridae family (CDV). Canine distemper is highly infectious and frequently lethal disease in dogs and has high mortality rate after rabies. The disease is transmitted through aerosol and the virus has high affinity to lymphocytes and macrophages (Greene and Appel, 1990). Canine distemper affects dogs, ferrets, skunks, raccoons, and foxes. The disease may harden the paws and nose, damage the teeth, make breathing difficult and diminish the appetite. Dogs that do not die usually suffer later in life from recurring neurological problems, such as nervous twitches and seizures (Ettinger and Feldman, 1995). Puppies from 3-6 months old are particularly susceptible. CDV spreads through aerosol droplets and through contact with infected bodily fluids, including nasal and ocular secretions, feces, and urine 6 - 22 days post exposure. It can also be spread by food and water contaminated with these fluids (Carter and Flores, 2006). The incubation 
period the disease is 14 - 18 days, although fever can appear from 3-6 days post infection (Appel and Summers, 1999).

The disease is known to cause acute generalized infection or chronic localized and persistent infection in the central nervous system of dogs (Stetler et al., 1997). Commonly observed signs are a runny nose, vomiting and diarrhea, dehydration, excessive salivation, coughing and/or labored breathing, loss of appetite, and weight loss and neurological signs such as incontinence (Jones et al., 1997). The typical pathologic features of canine distemper include lymphoid depletion (causing immunosuppression and leading to secondary infections), thrombocytopaenia, interstitial pneumonia, encephalitis with demyelination, and hyperkeratosis of the nose and foot pads (Ettinger and Feldman, 1995; Appel and Summers, 1999).

Dogs that survive distemper may continue to have both nonlife-threatening and lifethreatening signs throughout its lifespan. The most prevalent nonlife-threatening symptom is hard pad disease. This is when a dog experiences the thickening of the skin on the pads of its paws, as well as the end of its nose. Another lasting symptom commonly is enamel hypoplasia. Puppies, especially, will have damage to the enamel of teeth that are not completely formed or those that have not yet grown through the gums. This is a result of the virus destroying the cells responsible for manufacturing the tooth enamel. These affected teeth tend to erode quickly (Rodeheffer et al., 2007).

The mortality rate of the virus largely depends on the immune status of the infected dogs. Puppies experience the highest mortality rate where complications such as pneumonia and encephalitis are more common (Hirsch and Zee, 1999). In older dogs that develop distemper, encephalomyelitis and vestibular disease may be present (Dewey, 2003).

Breeding of dogs which according to Nikolai et al., (2011) is man's best friend has also become a source of livelihood to Nigerians in both urban and rural areas. The decline in productivity leading to economic wastage can be connected to many disease problems which are mostly viral in nature. The prevention of such diseases like canine distemper through vaccination has witnessed some challenges such as vaccination failure (Babalola et al., 2015). Canine distemper is an important disease in dogs which can be prevented by vaccination. The duration of the antibody produced by the vaccines could differ due to interference by maternal antibodies (Charmichael, 1980), and other factors such concurrent diseases. It has also been reported that some dogs were infected with the disease despite 
being vaccinated. This could be attributed to inability to mount a protective immunity response by the vaccine in the dogs. There is also paucity in the information about post vaccination antibody assessment in dogs and dog owners' response to canine distemper vaccination in the study area. Therefore there is need to evaluate the post vaccination antibody level in dogs to canine distemper conferred by the vaccine in the vaccinated dogs and evaluate the response of the owners to canine distemper vaccination program. This will help to prevent and control this endemic disease in Nigeria.

\section{MATERIALS AND METHOD}

This research work was carried out in six veterinary clinics in Jos North and South local government areas of Plateau State. The materials used include immunocomb ELISA kit, non-anticoagulant blood sample containers, sixty canine distemper vaccinated dogs, syringes and needles, disposable gloves, questionnaire, centrifuge machine, methylated spirit, cotton wool.

\section{Sample collection}

Ten sera samples were collected from each veterinary clinic through the cephalic vein of the dogs. The sites were aseptically prepared using swabs soaked in methylated spirit. Each blood sample was transferred into a sterile, non-heparinized plastic test tube and kept on a slanting position to allowed proper clotting. The samples were centrifuged at 3000 rpm for 15 minutes for proper separation in the Biochemistry laboratory of the Federal College of Animal Health and Production Technology Vom.

\section{Methodology}

Antibody (immunoglobulin G) titers were determined on serum samples using the Immunocomb ${ }^{\mathrm{TM}}$ ELISA solid phase immunoassay kit for canine distemper antibody detection. Capillary tubes were used to obtained $5 \mu$ of the sera and deposited into the well in row A. The lower pipette plunger was moved several times to achieve mixing. The tweezers was used to pierce the protective aluminum cover of row A. The comb was removed from its protective envelope and then inserted into the open wells in row A(with the printed side facing the researcher) and then incubated for 5 minutes. To improve mixing, comb was gently moved up and down (each row). This motion was repeated twice in all of the remaining rows $(\mathrm{B}, \mathrm{C}, \mathrm{D}, \mathrm{E}$ and $\mathrm{F})$. The comb was then taken out and allowed to dry for ten minute, tweezers was then used to pierce the foil of the next well (row B), and comb inserted for 2 minutes. Before transferring the comb from one well to the next, the excess liquid was gently shacked off from the comb teeth onto a tissue paper. The 
comb was inserted into the next well (row C) for 5 minutes and was placed into the remaining wells (rows D \& E) for 2 minutes each and the last well (row F) for 5 minutes. Upon completion of the color development in row $\mathrm{F}$, the comb was moved back to row $\mathrm{E}$ for 2 minutes for color fixation,

The concentration of CDV antibodies for each sample was measured using a color-coded scale provided in the kit. The results were expressed in "S" units on a scale of $0-6$, where 3 and above was considered as protective titer. Sera with IgG titers of "S - values" 4 were equivalent to $1: 160 ; 5$ were equivalent to $1: 320$ and 6 were equivalent to $1: 640$, for $\mathrm{CDV}$ (Biogal, 2007; Babalola et al., 2015).

\section{Data Analysis}

The data obtained were subjected to Chi-Square analysis, Probability of $\mathrm{P}<0.05$ was used to consider the significant. The results were presented in the form of tables and graphs.

\section{RESULT}

The result revealed that $54(90.0 \%)$ of the sampled dogs have protective immunity, with those given more than one dose having higher level of protective antibody. Out of the males and females dogs sampled, 19 (79.2\%) and 35 (97.2\%) had protective antibody titre while 5 $(20.8 \%)$ and $1(2.8 \%)$ had no protective immune titre respectively. Based on the antibody titre among the male dogs, $5(26.3 \%)$ were highly protected, $3(15.8 \%)$ were moderately protected, 9 (47.4\%) were mildly protected, while 2 (10.5\%) were lowly protected. Among the females, 7 (19.4\%) where highly protected, 12 (33.3\%) were moderately protected, $9(25 \%)$ were mildly protected while $7(19.4 \%)$ were lowly protected with no significant difference statistically $(\mathrm{p}>0.05)$ (Table 1$)$.

Table 1: Relationship between antibody and sex in vaccinated dogs

\begin{tabular}{|c|c|c|c|c|c|c|c|c|}
\hline \multicolumn{5}{|c|}{ Non - protective } & \multicolumn{3}{|c|}{ Protective } & \multirow[b]{2}{*}{ Total } \\
\hline $\begin{array}{l}\text { Sex/Antibody } \\
\text { titre }\end{array}$ & 0 & 1 & 2 & 3 & 4 & 5 & 6 & \\
\hline Male & 2 & 0 & 3 & $\begin{array}{l}2 \\
(10.5 \%)\end{array}$ & $\begin{array}{l}9 \\
(47.4 \%)\end{array}$ & $\begin{array}{l}3 \\
(15.8 \%)\end{array}$ & $\begin{array}{l}5 \\
(26.0 \%)\end{array}$ & $\begin{array}{l}24 \\
(40.0 \%)\end{array}$ \\
\hline Female & 0 & 0 & 1 & $\begin{array}{l}7 \\
(19.4 \%)\end{array}$ & $\begin{array}{l}9 \\
(25.7 \%)\end{array}$ & $\begin{array}{l}12 \\
(33.3 \%)\end{array}$ & $\begin{array}{l}7 \\
(19.4 \%)\end{array}$ & $\begin{array}{l}36 \\
(60.0 \%)\end{array}$ \\
\hline Total & $\begin{array}{l}2 \\
(3.3 \%)\end{array}$ & 0 & $\begin{array}{l}4 \\
(6.7 \%)\end{array}$ & $\begin{array}{l}9 \\
(15 \%)\end{array}$ & $\begin{array}{l}18 \\
(30 \%)\end{array}$ & $\begin{array}{l}15 \\
(25 \%)\end{array}$ & $\begin{array}{l}12 \\
(20 \%)\end{array}$ & $\begin{array}{l}60 \\
(100.0 \%)\end{array}$ \\
\hline
\end{tabular}

$\mathrm{X}^{2}$ cal: 0.87; $(\mathrm{p}<0.05) ; \mathrm{X}^{2}$ crit: 3.84; Degree freedom (2-1) $(2-1)=1$

Among the adults, $40(93.0 \%)$ had protective antibody titre while $3(7.0 \%)$ were not protected. The antibody titre showed that $9(22.5 \%)$ were highly protected, $12(30.0 \%)$ were 
moderately protected, $13(32.5 \%)$ were mildly protected while $6(15.0 \%)$ were lowly protected. Out of the puppies $14(82.4 \%)$ had protective immunity while $3(17.6 \%)$. The antibody titre also revealed that, 3 (21.4\%) where highly protected, 3 (21.4\%) were moderately protected, 5(35.7\%) were mildly protected while $3(21.4 \%)$ where lowly protected ( $\mathrm{S}-$ value 3$)$ with no statistical significant difference $(\mathrm{p}>0.05)$ (Table 2$)$.

Table 2: Relationship between antibody titre and age in vaccinated dogs

\begin{tabular}{l|lll|llll|r}
\hline \multicolumn{7}{c}{ Non protective } & \multicolumn{7}{c}{ Protective } \\
\hline Age/immunity & 0 & 1 & 2 & 3 & 4 & 5 & 6 & Total \\
Adult & 1 & 0 & $2(5 \%)$ & $6(15 \%)$ & $13(32.5 \%)$ & $12(30 \%)$ & $9(22.5 \%)$ & $43(71.7 \%)$ \\
Puppies & 1 & 0 & $2(5 \%)$ & $3(21.4 \%)$ & $5(35.7 \%)$ & $3(21.4 \%)$ & $3(21.4 \%)$ & $17(28.3 \%)$ \\
Total & $2(3.3 \%)$ & 0 & $4(6.7 \%)$ & $9(15 \%)$ & $18(30 \%)$ & $15(25 \%)$ & $12(20 \%)$ & $60(100.0 \%)$ \\
\hline
\end{tabular}

$\mathrm{X}^{2}$ cal: $0.46 ;(\mathrm{P}<0.05) ; \mathrm{X}^{2}$ crit: 3.84; Degree of freedom $(2-1)(2-1)=1$

The result showed that the total number of dogs that received single, double and triple vaccinations were $5(8.33 \%), 4(6.67 \%)$ and $51(85.0 \%)$ respectively. Out of the single vaccinated animals, $4(80.0 \%)$ had protective immunity while $1(20.0 \%)$ did not. Out of the animals administered double vaccinations, 4 (100.0\%) had protective immunity while among those that were given triple vaccinations, $46(90.2 \%)$ had protective immunity while $5(9.8 \%)$ had no protective immunity. Statistically, the results showed that there was significant difference $(p<0.05)$ in the animals between the antibody titre and the number of primary vaccination (Table 3 ).

Table 3: Relationship between antibody (IgG) titre and primary doses

\begin{tabular}{l|lll|llll|l}
\hline \multicolumn{9}{c}{ Non Protective } \\
\hline doses/immunity & 0 & 1 & 2 & 3 & 4 & 5 & 6 & Total \\
\hline Single & 0 & 0 & 1 & $2(40.0 \%)$ & $2(40.0 \%)$ & $0(0.0 \%)$ & $0(0.0 \%)$ & $5(8.33 \%)$ \\
Double & 0 & 0 & 0 & $1(25.0 \%)$ & $1(25.0 \%)$ & $1(25.0 \%)$ & $1(25.0 \%)$ & $4(6.67 \%)$ \\
Triple & 2 & 0 & 3 & $6(13.0 \%)$ & $15(32.6 \%)$ & $14(30.4 \%)$ & $11(23.9 \%)$ & $51(85.0 \%)$ \\
Total & $2(3.3 \%)$ & $0(0.0 \%)$ & $4(6.7 \%)$ & $9(15 \%)$ & $18(30 \%)$ & $15(25 \%)$ & $12(20 \%)$ & $60(100 \%)$ \\
\hline
\end{tabular}

$\mathrm{X}^{2}$ cal: $18.7 ;(\mathrm{P}<0.05) ; \mathrm{X}^{2}$ crit: 5.99; Degree of freedom (3-1) $(2-1)=2$

In relation to secondary revaccination (Table 4) the result showed that the total number of those among adults revaccinated and those not revaccinated were $22(51.2 \%)$ and 21 $(49.8 \%)$ respectively. Out of those revaccinated animals, $19(86.0 \%)$ had protective 
immunity while $3(13.6 \%)$ were not protected. Based on the antibody titre, $6(31.0 \%)$ were highly protected, $6(31.5 \%)$ were moderately protected, 4 (21.5\%) were mildly protected (S value 4$)$, while $3(15.8 \%)$ were lowly protected. Out of those non-revaccinated animals, 5 (23.8.0\%) had protective immunity while 16 (76.2.6\%) were not protected. Based on the protective antibody titre among non-revaccinated animals, 5 (100\%) where lowly protected. The antibody titres differed significantly $(\mathrm{p}<0.05)$ between the dogs administered booster dose of the vaccine (secondary vaccination) and those that were not given.

Table 4: Relationship between antibody (IgG) titre and secondary vaccination (booster) in vaccinated adult dogs

\begin{tabular}{l|lll|llll|l}
\hline \multicolumn{7}{c}{ Non Protective (\%) } & \multicolumn{7}{c}{ Protective (\%) } & Total \\
\hline Booster/immunity & 0 & 1 & 2 & 3 & 4 & 5 & 6 & \\
\hline Yes & 1 & 0 & 2 & $3(15.8)$ & $6(31.6)$ & $6(31.6)$ & $4(21.1)$ & $22(51.2)$ \\
No & 0 & 0 & 2 & $1(5.3 \%)$ & $7(36.8)$ & $6(31.6)$ & $5(26.3)$ & $21(48.8)$ \\
Total & $1(2.3)$ & 0 & $4(9.3)$ & $4(9.3)$ & $13(30.2)$ & $12(27.9)$ & $9(20.9)$ & $43(100)$ \\
& & & & & & & & \\
\end{tabular}

$\mathrm{X}^{2}$ cal: 1.58; $(\mathrm{P}<0.05) ; \quad \mathrm{X}^{2}$ crit: 3.84; Degree of freedom $(2-1)(2-1)=1$.

\section{DISCUSSION}

Results obtained from this study showed that some dogs vaccinated against CDV using commercially available CDV multivalent vaccine showed protective antibody titers. In this area of study, CDV is endemic and is the cause of clinically important diseases in dogs associated with high mortality and morbidity rates. This correlated well with what was reported in literature (Eghafona., et al 2007; Nwoha and Anene, 2015). Investigation of immune status following vaccination using standard procedures like the hemagglutination inhibition (HI), serum neutralization (SN) and immunofluorescent antibody (IFA) has not been practicable in Nigeria in view of the cost and other limitations associated with these tests (such as trained personnel and time constraint) as has been the case even in some advanced countries of the world (Waner et al., 2004). Thus, the use of a rapid inclinic immunoblot ELISA technique for the semi quantitative analyses of antibody titers to CDV provides solution to this limitation (Eghafona et al., 2007). This technique has been used to 
assess antibody response of pups after primary vaccination and the persistence of serum antibody titers to specific infectious diseases in adult dogs as revealed in literature (Waner, 2002; Waner et al., 2003; Waner and Keren-Kornblatt, 2006).

In this study, data was collected from 60 vaccinated dogs of different sexes, ages and breeds so as to give a broader picture of dogs' antibody response to vaccination. Findings revealed that some dogs did not show protective antibody titre despite vaccination. This is attributable to the fact that, there was vaccination failure (Eghafona et al., 2007). Reports have revealed that, vaccine failure can result from the effect of maternally derived antibody or passively acquired antibodies at time of vaccination, delay in maturation of the immune system, poor vaccinal immunogenicity, genetic inability to respond to certain vaccine antigens, immune-suppression and ineffective lots of vaccine (Schultz, 2000; 2006). It has also been reported that some dogs never appeared to mount an adequate antibody response to vaccination (Twark and Dodds, 2000). If however, there is low antibody response to vaccination due to vaccination failure, revaccination may be required. In such a case, the use of immunoblot ELISA assay in determining when to vaccinate dogs will be significant (Eghafona et al., 2007).

All ages, sexes and breeds of dogs sampled showed no significant association $(\mathrm{P}>0.05)$ with adequate CDV serum antibody titers. Earlier works by Greene and Appel, (1998), Twark and Dodds (2000) and Eghafona et al., (2007) reported that sex, age and breed showed no significant association (where $\mathrm{P}>0.05$ ) with CDV serum antibody titer. This is also in agreement with what was reported in the literatures (Waner et al., 2004; Waner and Keren-Kornblatt, 2006) but disagreed with Babalola et al (2015) who reported that gender affected the susceptibility of dogs to canine distemper.

There was a significant association $(\mathrm{P}<0.05)$ between the number of primary doses and the antibody titre. Adequate vaccination has remained the most cost-effective way of preventing CDV in pet animals. Primary vaccinations comprise three initial doses of vaccine within early life of the animal. According to Wanner et al (1998), this could be done between 8 - 16 weeks of age of the dog. Tizard, (1998), Waner et al. (2004); Oyedele et al (2004) and Schultz (2006), complete administration of primary doses of vaccine against CDV enhances adequate production of antibodies against the disease Schultz, (200) and Nwoha and Anene (2015) reported that secondary vaccinations increase antibody titre, against the disease thereby increasing protecting the animal against the disease.

The result of secondary (booster) vaccination showed a significant difference $(\mathrm{P}<0.05)$ when compared with the antibody titre. The animals that were given booster dose of canine 
distemper vaccine showed higher antibody titre than those that were not given. This was in accordance with Latha et al., 2006; Eghafona et al. (2007) and Nwoha and Anene (2015) who state that secondary vaccinations increase the antibody titre in the animal.

\section{CONCLUSION/RECOMMENDATIONS}

In conclusion, dogs that were vaccinated with full doses of primary vaccination against canine distemper had more protective antibody titre and also, those that received booster doses (secondary vaccination) had also more protective antibody. This present study clearly confirms post-vaccination immunity for canine distemper fractions in a commercial multivalent modified-Live virus vaccine. Serological testing of post- vaccination immunity can allow for the establishment of more cost-effective vaccines and vaccination schedules, elimination of unnecessary revaccinations and clients could be provided with a scientifically based rationale for use of vaccines. The end result therefore would be an improvement in the overall health of animals. In this study, the diagnostic value of using the immunoblot ELISA assay for the rapid detection of CDV IgG is in total agreement with what was reported in previous studies. Instances where IgG antibody titres are low in dogs previously vaccinated, revaccination becomes necessary. Where IgG levels are low in conditions of natural infections as occurs in CDV infected dogs, accurate early diagnosis and prompt treatment of cases become very easy.

It was therefore recommended that the 3 shot vaccination schedule in young dogs and annual revaccination of adult dogs be adhered to in order to attain maximum immune response.

\section{REFERENCE}

Appel, M.J.G and Summers, B.A. Canine distemper: current status. Recent Advances in Canine infectious diseases; 1999, 3: 25-30.

Babalola, E. T., Olakunbi, O. S., Omoshaba, E. O., Okonko, I. O. 2015 Seropositivity of Canine Distemper Virus (CDV) in Dogs Presenting at Abeokuta, Nigeria. Public Health Research 2015, 5(4): 109-119.

Biogal, D. Immunosorbent Assay for Evaluation of the Immune Status to Canine Parvovirus and Distemper virus in Adult Dogs Before Revaccination. Journal Veterinary Diagnostic Investigation; 2007, 18(3): 267-270.

Carmichael, L. E. Immunization strategies in puppies - Why failures? Comparison. Continuation. Education Practical Veterinary; 1980, 5:1043-1051. 
Carter, G.R; Flores, E.F; Wise, D.J. Paramyxoviridae. A concise review of veterinary virology; 2006, 3:126-129.

Dewey, C.W. A practical guide to canine and feline neurology. Iowa state University, Animal practical; 2003, 124 (1), 12-17.

Eghafona, N. O; Jacob, J; Yah, S. C. Evaluation of post-vaccination immunity to canine distemper and parvoviruses in Benin city, Nigeria. African Journal of Biotechnology; 2007, 6 (16), 1898-1904.

Ettinger, S. J; Feldman, E. C. Textbook of veterinary internal medicine ( $4^{\text {th }}$ ed.). W.B. saunders company; 1995, 36-41. ISBN 0-72166705-3

Greene CE, Appel MJ. Canine Distemper. In: Greene CE (ed).Infectious Diseases of the Dog and Cat, 2nd edition, W.B. Saunders Company. 1998, p. 9-22.

Greene, G. E and Appel M. J. Canine distemper. in: Greene, G. E. (ed.). infectious diseases of the $\operatorname{dog}$ and cat. W. B. Saunders, Philadelphia, Pennsylvania; 1990, 226-241.

Greene, C.E. and Appel, M.J. Canine distemper in infectious diseases of the dog and cat. Edited by C.E. Greene (W B saunders company, Philadelphia. 1998. 9-22); 1998.

Hirsh D.C; Zee Y.C. Canine distemper: prevention of infections veterinary microbiology. blackwell publishing; 1999, 311: 452-486. ISBN 978-0-86542-543-9.

Jones, T.C. Hunt, R.D. King, N.W. Degenerative Diseases. Veterinary Pathology. Blackwell Publishing; 1997, 328 (1) 45-137.

Latha, D; Srinivasan, S.R; Thirunavukkarasu, P.S; Gunaselan, L.; Ramadass, P; Narayanan, R.B. Assessment of canine distemper virus infection in vaccinated and unvaccinated dogs. Indian Journal Biotechnolog; 2006, 6, 35-40.

Nikolai D. O; Susan J. C; Yaroslav V. K; Thomas F. G. H; Gregory W. L; Hodgins, J; Van, D. P. A 33-Year-Old Incipient Dog from the Altai Mountains of Siberia: Evidence of the Earliest Domestication Disrupted by the Last Glacial Maximum. Journal Pone; 2011, 1-3.

Nwoha RIO, Anene BM. An Assessment of Immune Response to Canine Distemper Vaccination in Dogs Experimentally Infected with Ancylostoma and Trypanosome. International Journal of Tropical Disease \& health. 2015; 7(2): 62-68.

Oyedele, O.I., oluwayelu, D.O., cadmus, S.I.B., odemuyiwa, S.O. \& adu, F.D. Protective levels of canine distemper virus antibody in an urban dog population using plaque reduction neutralization test. Onderstepoort Journal of Veterinary Research; 2004, 71:227-230.

Rodeheffer, C; Von M, V; Milot, S; Lepine, F; Manges, A.R; Ward, B.J. Disease manifestations of canine distemper virus infection in ferrets are modulated by vitamin A status. The Journal of nutrition; 2007137 (8): 1916-22. 
Schultz R.D. Considerations in designing Effective and Safe Vaccination Programs, Veterinary Medicine; 2000 93:233-254.

Schultz, R.D. Duration of immunity for canine and feline vaccines: A review. Veterinary Microbiology, 2006, 117: 75-79

Stetler M. Beck K; Wagner A; Vandevelde M; Zurbriggen A. Determinants of persistence in canine distemper virus. Veterinary microbiology. 1997, 57, 83-95.

Tizzard, I. Yawei, N.I. 1998. Use of serologic testing to assess immune status of companion animals, Journal of American Veterinary Medicine Association, 213: 54-60.

Twark, L. Dodds, W. J. Clinical use of serum parvovirus and distemper virus antibody titers for determining revaccination strategies in healthy dogs. Journal American Veterinary Association; 2000, 7: 217(1): 1021-1024.

Waner T, Mazar S, Nachmias E, Keren-Kornblatt E, Harrus S. Evaluation of a dot ELISA kit for measuring immunoglobulin $\mathrm{M}$ antibodies to canine parvovirus and distemper virus. Veterinary Record. 2003; 152:588-591.

Waner, T. Response of puppies to vaccination to canine distemper virus and canine parvovirus. 27th WSAVA Congress, Granada, Spain, 2002

Waner, T. A Review of Current International Vaccination Trends for Dogs and Cats. Are We Up To Date and. In-Line with Contemporary Thinking? Journal Israel Veterinary Medicine Association 2004, 59(3): 84-102. www.isrvma.org/article/59 3 1.htm

Waner, T. Keren kornblatt, E. Shemesh O. Mazar S. Diagnosis of acute canine parvovirus infection (CPV) in naturally infected Dogs using IgM and IgG rapid dot Elisa. Journal Israel Veterinary Medicine Association; 2004, 59(1-2): 12-15.

Waner, T; Mazar S. Keren-Kornblatt, E. Application of a Dot Enzyme-Linked Immunosorbent Assay for Evaluation of the Immune Status to Canine Parvovirus and Distemper virus in Adult Dogs Before Revaccination. Journal of Veterinary Diagnosis Investigation; 2006, 18(3): 267-270.

Waner, T; Mazar, S; Nachmias, E; Keren, K.E; Harrus, S. Assessment of maternal antibody decay and response to canine parvovirus vaccination using an enzyme linked immunosorbent assay. Journal of Veterinary Diagnosis Investigation; 1998, 8: $427-432$. 


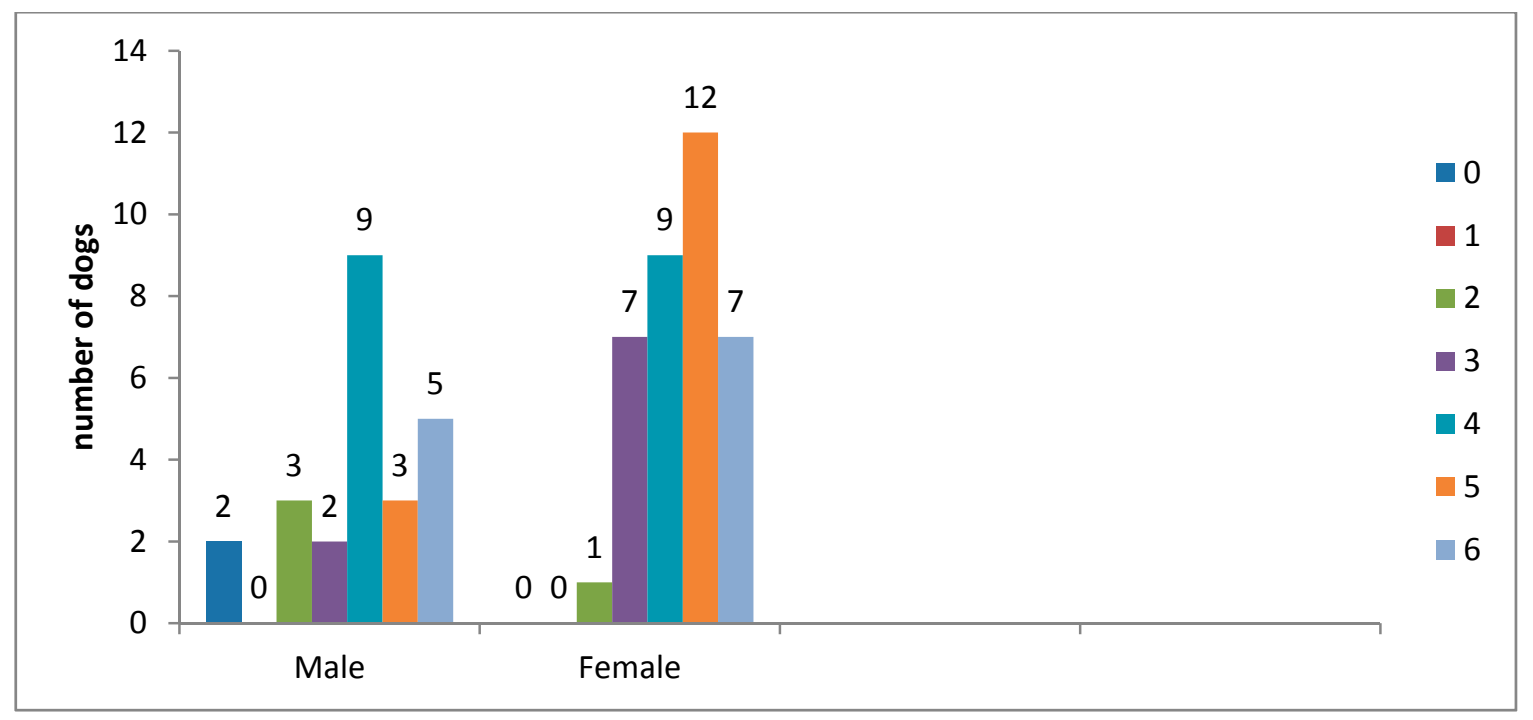

Figure 1: Relationship between Antibody (IgG) titre and Sex

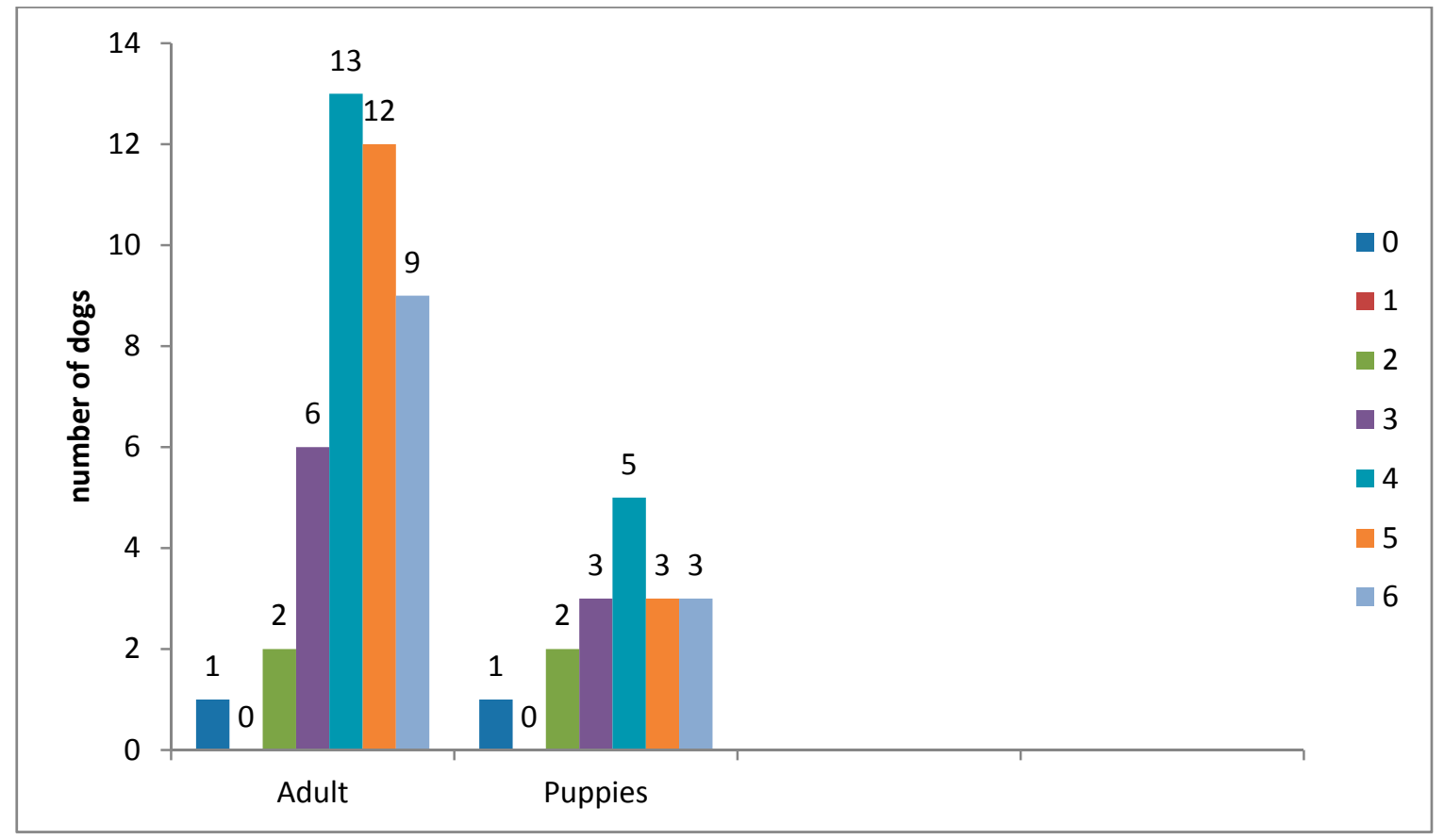

Figure 2: Relationship between Antibody (IgG) titre and Age 


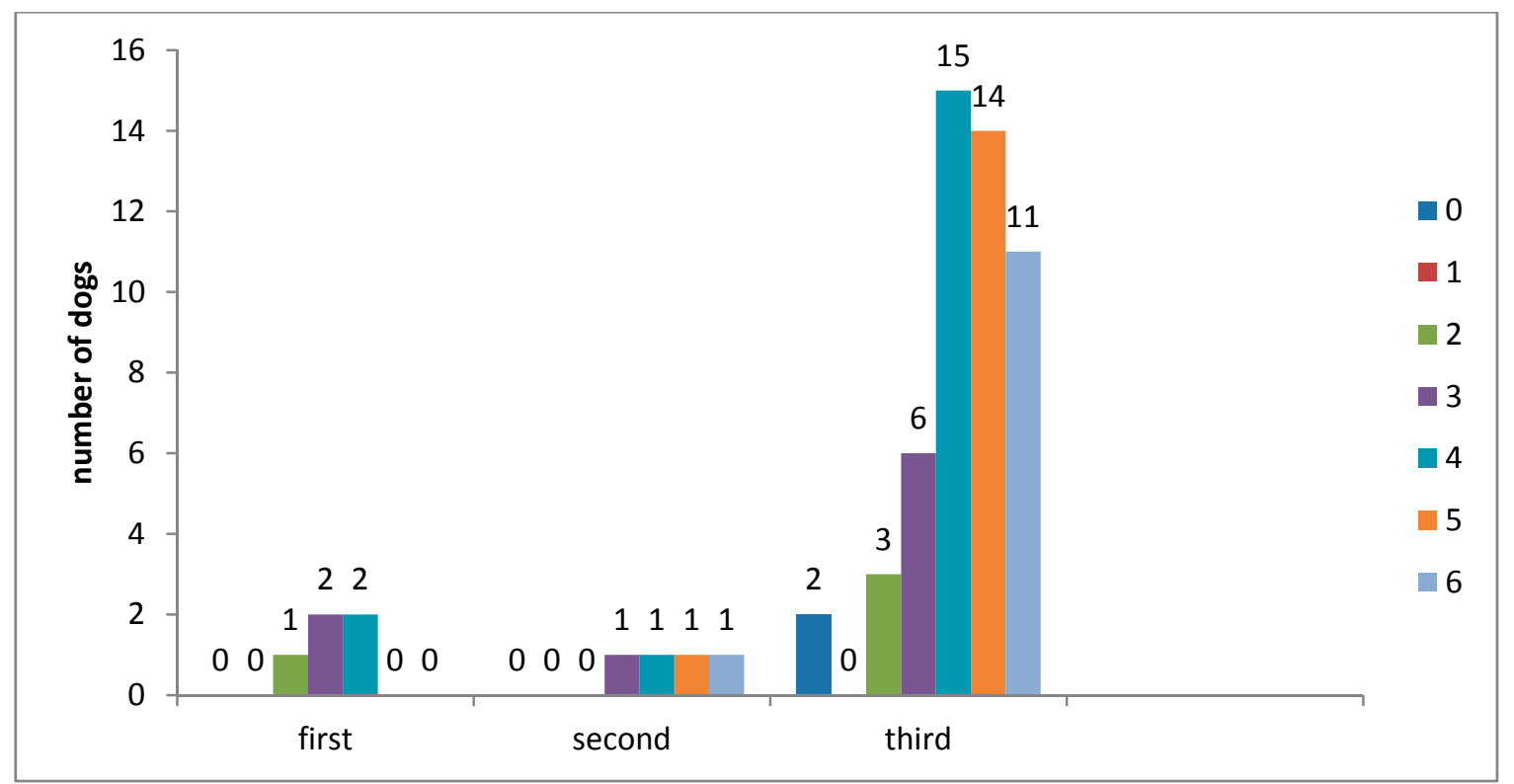

Figure 3: relationship between Antibody ( $\operatorname{IgG})$ titre and Primary vaccination

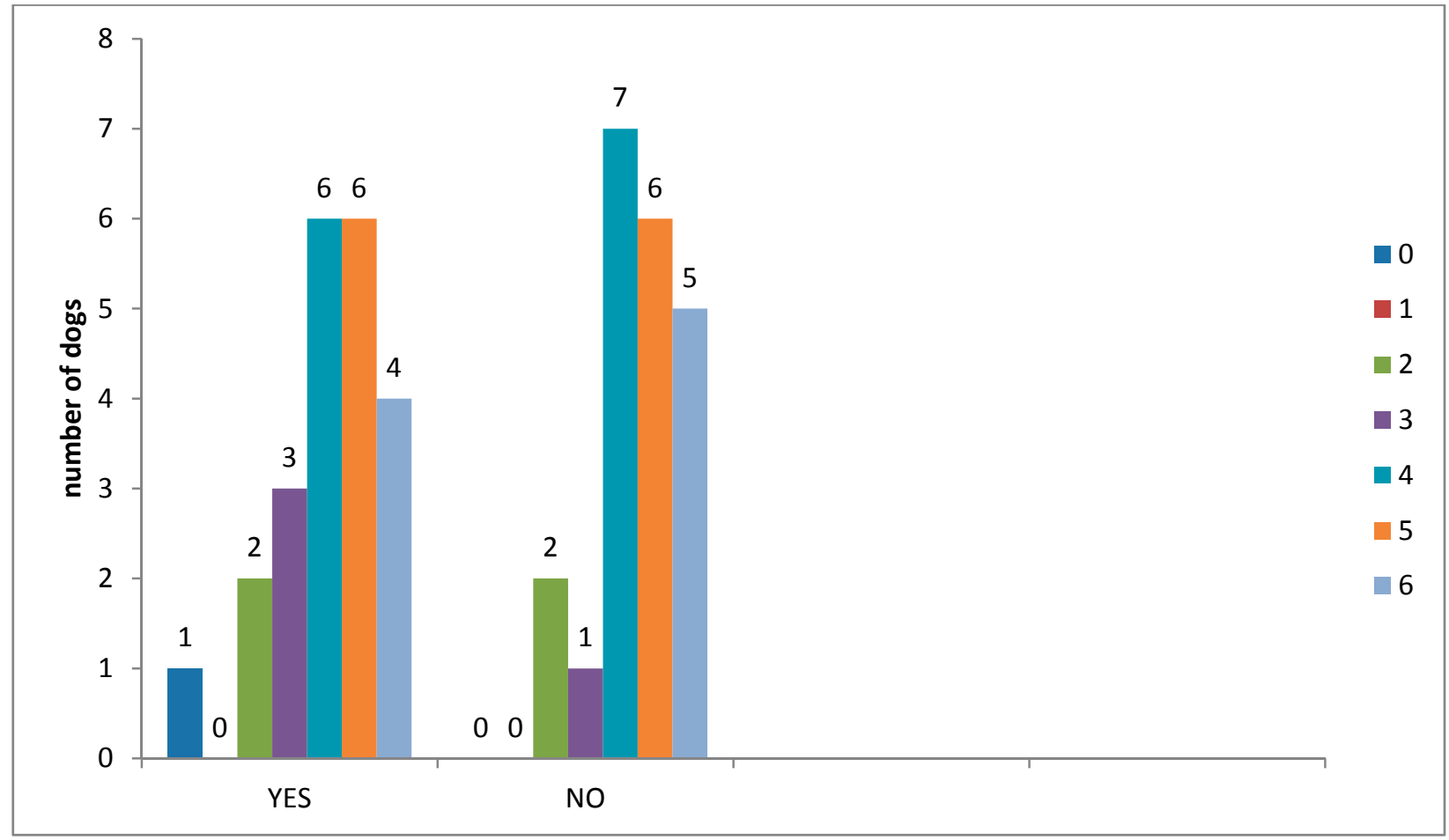

Figure 4: relationship between Antibody (IgG) titre and Secondary vaccination

(C) 2016 by the author; licensee Preprints, Basel, Switzerland. This article is an open access article distributed under the terms and conditions of the Creative Commons by Attribution (CC-BY) license (http://creativecommons.org/licenses/by/4.0/). 